NASA/TM-2010-215591

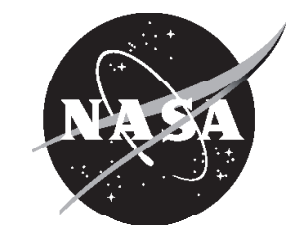

\title{
Comparison of ISRU Excavation System Model Blade Force Methodology and Experimental Results
}

\author{
Christopher A. Gallo and R. Allen Wilkinson
}

Glenn Research Center, Cleveland, Ohio

Robert P. Mueller

Kennedy Space Center, Kennedy Space Center, Florida

Jason M. Schuler and Andrew J. Nick

ASRC Aerospace Corporation, Kennedy Space Center, Florida 


\section{NASA STI Program . . . in Profile}

Since its founding, NASA has been dedicated to the advancement of aeronautics and space science. The NASA Scientific and Technical Information (STI) program plays a key part in helping NASA maintain this important role.

The NASA STI Program operates under the auspices of the Agency Chief Information Officer. It collects, organizes, provides for archiving, and disseminates NASA's STI. The NASA STI program provides access to the NASA Aeronautics and Space Database and its public interface, the NASA Technical Reports Server, thus providing one of the largest collections of aeronautical and space science STI in the world. Results are published in both non-NASA channels and by NASA in the NASA STI Report Series, which includes the following report types:

- TECHNICAL PUBLICATION. Reports of completed research or a major significant phase of research that present the results of NASA programs and include extensive data or theoretical analysis. Includes compilations of significant scientific and technical data and information deemed to be of continuing reference value. NASA counterpart of peer-reviewed formal professional papers but has less stringent limitations on manuscript length and extent of graphic presentations.

- TECHNICAL MEMORANDUM. Scientific and technical findings that are preliminary or of specialized interest, e.g., quick release reports, working papers, and bibliographies that contain minimal annotation. Does not contain extensive analysis.

- CONTRACTOR REPORT. Scientific and technical findings by NASA-sponsored contractors and grantees.
- CONFERENCE PUBLICATION. Collected papers from scientific and technical conferences, symposia, seminars, or other meetings sponsored or cosponsored by NASA.

- SPECIAL PUBLICATION. Scientific, technical, or historical information from NASA programs, projects, and missions, often concerned with subjects having substantial public interest.

- TECHNICAL TRANSLATION. Englishlanguage translations of foreign scientific and technical material pertinent to NASA's mission.

Specialized services also include creating custom thesauri, building customized databases, organizing and publishing research results.

For more information about the NASA STI program, see the following:

- Access the NASA STI program home page at http://www.sti.nasa.gov

- E-mail your question via the Internet to help@ sti.nasa.gov

- Fax your question to the NASA STI Help Desk at $443-757-5803$

- Telephone the NASA STI Help Desk at 443-757-5802

- Write to: NASA Center for AeroSpace Information (CASI) 7115 Standard Drive Hanover, MD 21076-1320 
NASA/TM-2010-215591

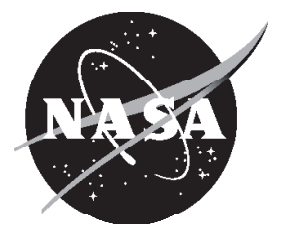

\section{Comparison of ISRU Excavation System Model Blade Force Methodology and Experimental Results}

Christopher A. Gallo and R. Allen Wilkinson

Glenn Research Center, Cleveland, Ohio

Robert P. Mueller

Kennedy Space Center, Kennedy Space Center, Florida

Jason M. Schuler and Andrew J. Nick

ASRC Aerospace Corporation, Kennedy Space Center, Florida

National Aeronautics and

Space Administration

Glenn Research Center

Cleveland, Ohio 44135 
Trade names and trademarks are used in this report for identification only. Their usage does not constitute an official endorsement, either expressed or implied, by the National Aeronautics and Space Administration.

Level of Review: This material has been technically reviewed by technical management.

Available from

NASA Center for Aerospace Information 7115 Standard Drive

Hanover, MD 21076-1320
National Technical Information Service 5301 Shawnee Road Alexandria, VA 22312

Available electronically at http://gltrs.grc.nasa.gov 


\title{
Comparison of ISRU Excavation System Model Blade Force Methodology and Experimental Results
}

\author{
Christopher A. Gallo and R. Allen Wilkinson \\ National Aeronautics and Space Administration \\ Glenn Research Center \\ Cleveland, Ohio 44135 \\ Robert P. Mueller \\ National Aeronautics and Space Administration \\ Kennedy Space Center \\ Kennedy Space Center, Florida 32899 \\ Jason M. Schuler and Andrew J. Nick \\ ASRC Aerospace Corporation \\ Kennedy Space Center, Florida 32899
}

\begin{abstract}
An Excavation System Model has been written to simulate the collection and transportation of regolith on the Moon. The calculations in this model include an estimation of the forces on the digging tool as a result of excavation into the regolith. Verification testing has been performed and the forces recorded from this testing were compared to the calculated theoretical data. A prototype lunar vehicle built at the NASA Johnson Space Center (JSC) was tested with a bulldozer type blade developed at the NASA Kennedy Space Center (KSC) attached to the front. This is the initial correlation of actual field test data to the blade forces calculated by the Excavation System Model and the test data followed similar trends with the predicted values. This testing occurred in soils developed at the NASA Glenn Research Center (GRC) which are a mixture of different types of sands and whose soil properties have been well characterized. Three separate analytical models are compared to the test data.
\end{abstract}

\section{Introduction}

An Excavation System model has been developed to simulate the excavation and transportation of regolith on the lunar surface. This system model includes equations that have been derived from terrestrial soil mechanics that are used to predict blade forces. The equations are coded in visual basic with an Microsoft Excel (Microsoft Corporation) spreadsheet used for the code input and output. Vehicle geometry, soil parameters, blade parameters and operating conditions are all specified in the input. The blade force is calculated using the equations developed by V.I. Balovnev (Ref. 1). The predicted blade force was then compared to test data obtained from field testing at the Johnson Space Center. Figure 1 shows a diagram of a blade illustrating the variables that are used in the force equations. 


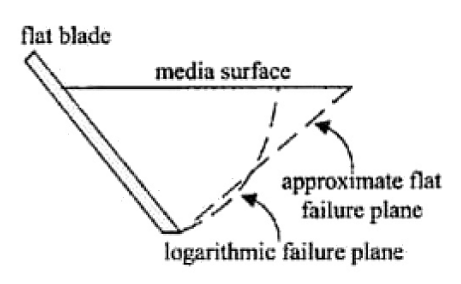

a) Cutting failure planes

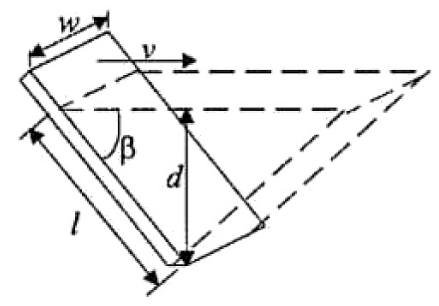

b) Cutting operation variables

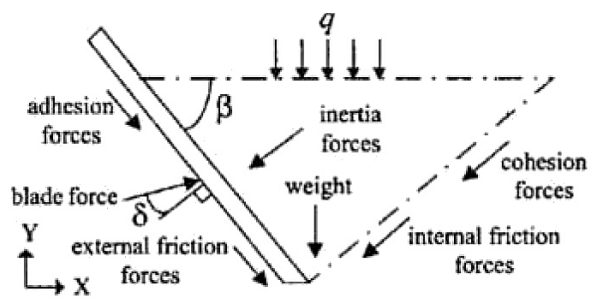

c) Cutting forces

Figure 1.-Blade diagram showing variables used in the equations (Ref. 4).

\section{Nomenclature}

$\alpha_{b}$ blunt edge angle

$\beta$ rake angle

$\gamma$ soil density

$\phi$ internal friction angle

$\delta$ external friction angle

$c$ cohesion

$d$ vertical cut depth

$e_{b}$ blunt edge thickness

$g$ gravitational constant

$h$ soil prism height

$l$ blade height from tip

$l_{s}$ blade side plate length

$q$ surcharge mass

$r$ blade radius

$s$ side plate thickness

$v$ vehicle velocity

$w$ blade width

\section{Background}

In July 2005, a task was initiated by the NASA Exploration Technology Development Program, InSitu Resource Utilization Project to develop a computer code to simulate excavation and transportation of regolith on the Moon. The code, designated the Excavation System Model, is a subset of an overall InSitu Resource Utilization (ISRU) System Model. The Excavation System Model consists of a separate Force Model and a Mass Model (Refs. 2 and 3). The force model calculates vehicle and bucket forces and the mass model performs structural calculations to size the required individual components based on inputs from the force model. A top level flow chart of the system model is shown in Figure 2. This system model can either size a vehicle based on a number of input parameters or can use the parameters of an existing vehicle that have been defined in the code.

The Excavation Model has evolved over the past four years by refining the coding methods and adding new capabilities. Testing of various excavation implements has begun and the data collected from the first tests has been compared to the results from the code. This testing will help validate the code so that vehicle operation on the Moon can be predicted with confidence. 


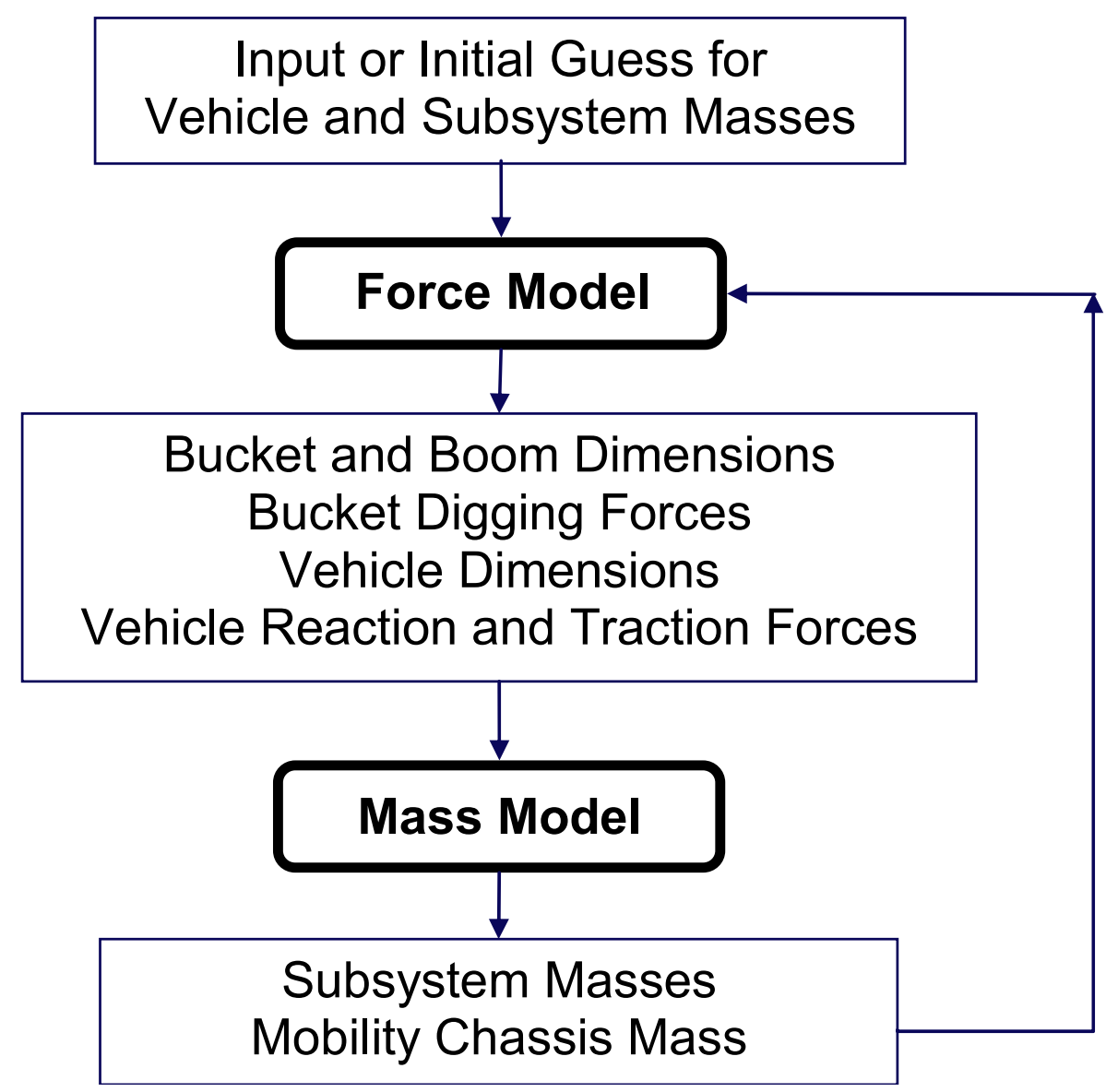

Figure 2.-Top level flow chart of excavation system model.

\section{Testing}

Figures 3 and 4 show a terrestrial prototype of the Lunar Vehicle with a $4.1 \mathrm{~m}$ wide bulldozer blade attached to the front. The vehicle was developed at the Johnson Space Center to test concepts for a multipurpose lunar rover when astronauts return to the Moon. The blade was developed at the Kennedy Space Center as part of the ISRU project. Two series of tests were performed at the Johnson Space Center. The first occurred during the week of May 5, 2008, and was performed in soil designated as GRC-1 which is a special blend of sands developed at the Glenn Research Center to mimic the lunar regolith particle size distribution. The second series of tests occurred during the week of November 17, 2008, in soil designated as GRC-3 which has a different mixture than the GRC-1 soil to yield different properties. The purpose of the testing was to drive the vehicle to push the soil simulating the grading of a lunar road or preparation of a landing pad. There are five load cells attached at the interface of the blade to the frame. Figure 5 shows the layout of the five load cells connected to the frame and Figures 6 and 7 show the vertical location of the two rows of load cells for the May and November test series. The force exerted on these load cells was recorded during the test along with the vehicle velocity and the blade depth into the soil at approximately $0.40 \mathrm{sec}$ intervals for the May test and $0.02 \mathrm{sec}$ intervals for the November test. Results from two of the May tests and four of the November tests are presented here. 


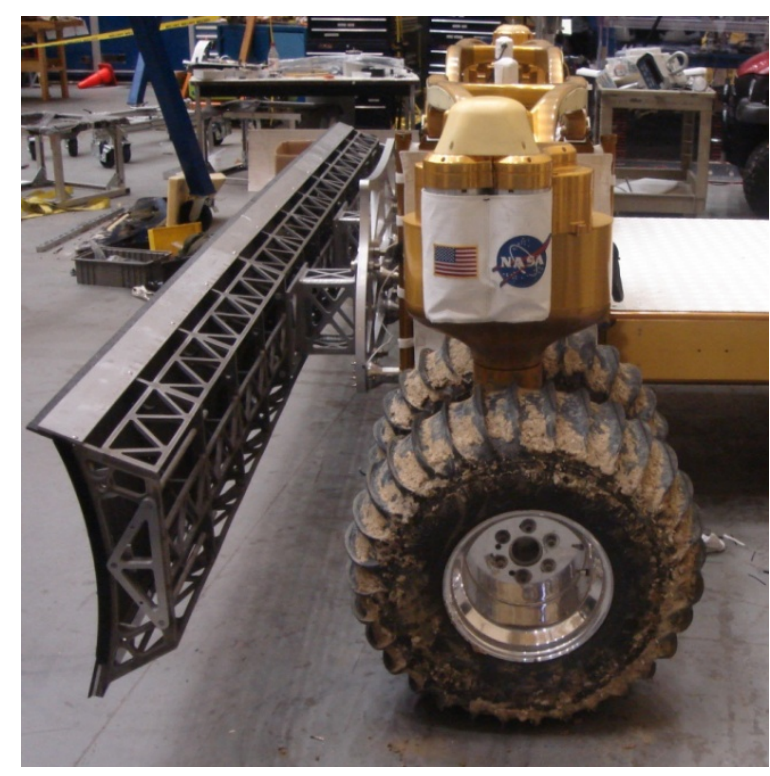

Figure 3.-Vehicle showing blade attachment in the lab at KSC.

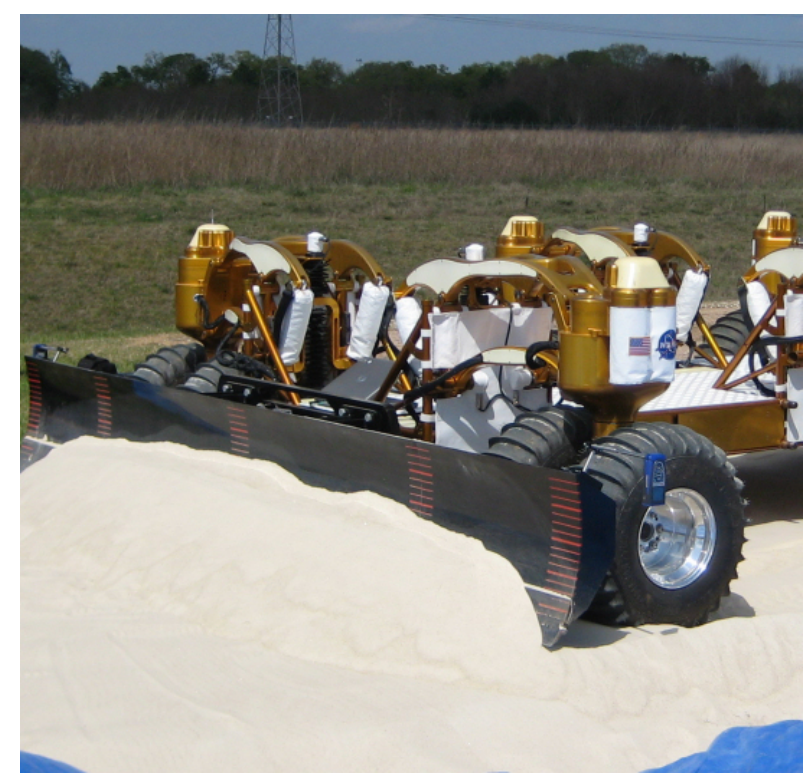

Figure 4.- Vehicle pushing GRC-1 soil at the JSC test site in May 2008.

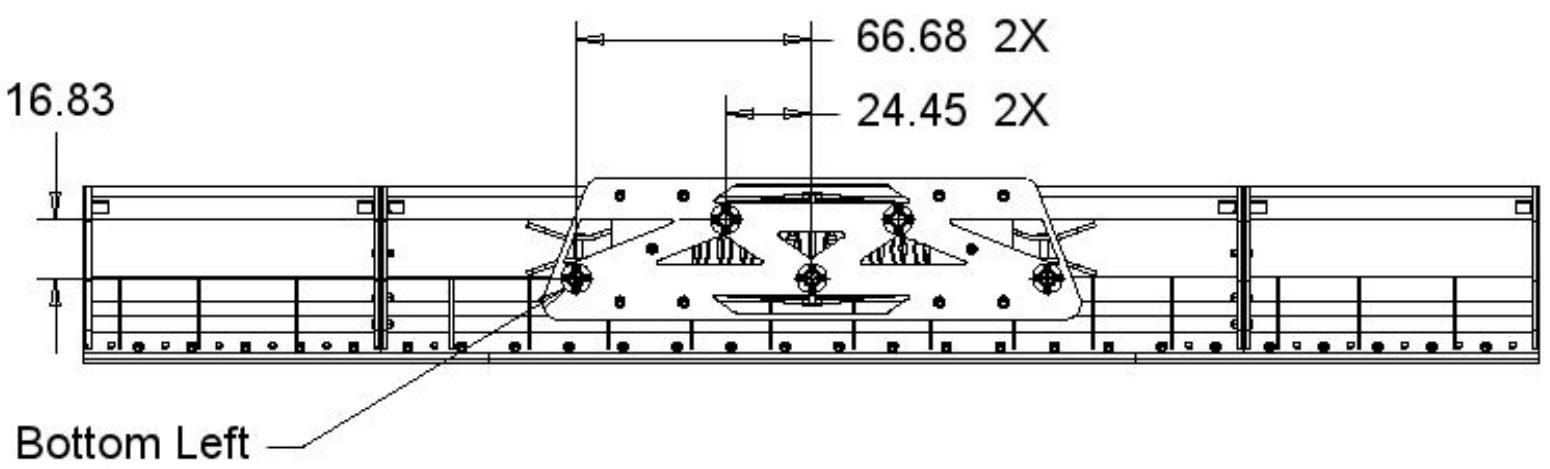

Figure 5.-End view behind blade showing five load cell locations (dimensions in centimeters). 


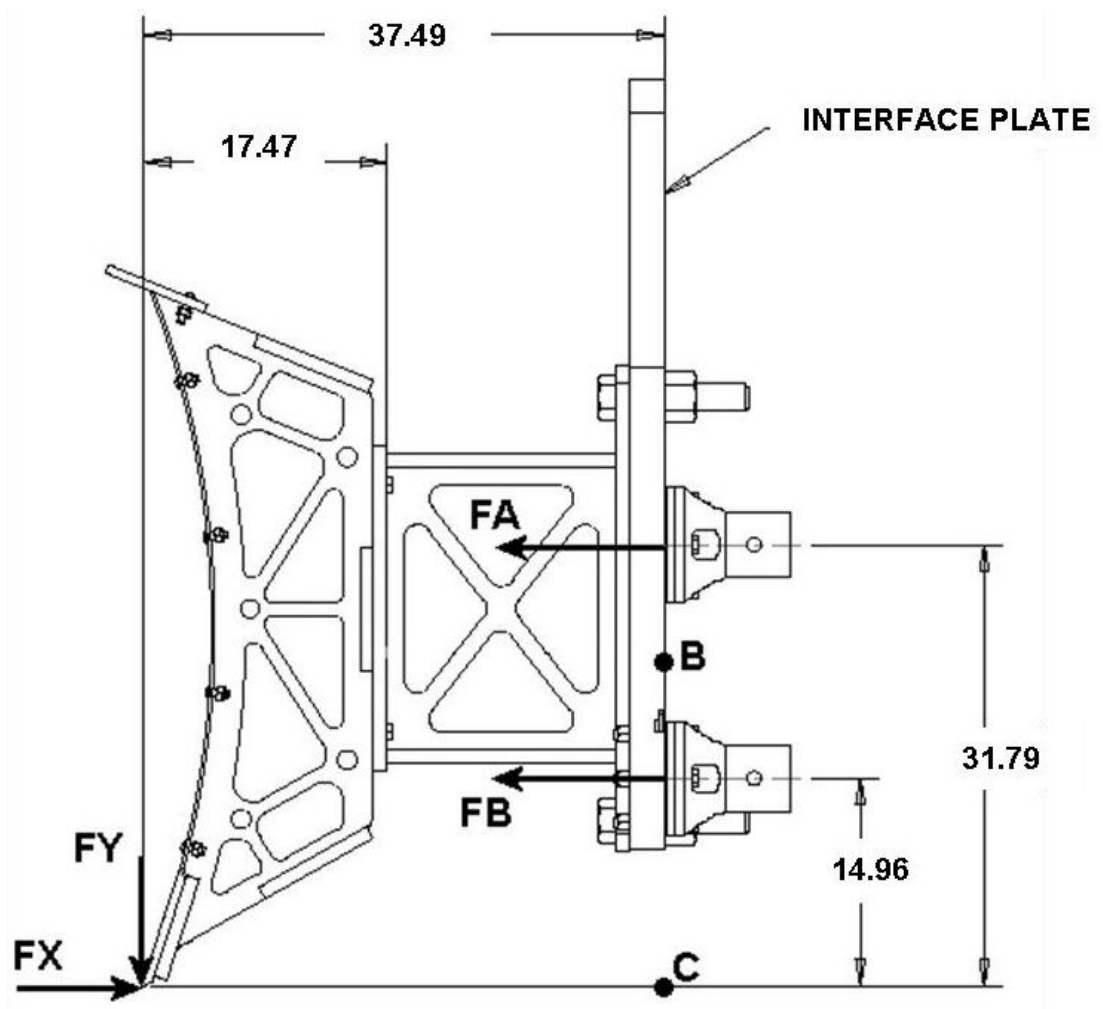

Figure 6.-Side view of blade showing top and bottom load cells for May test (dimensions in centimeters).

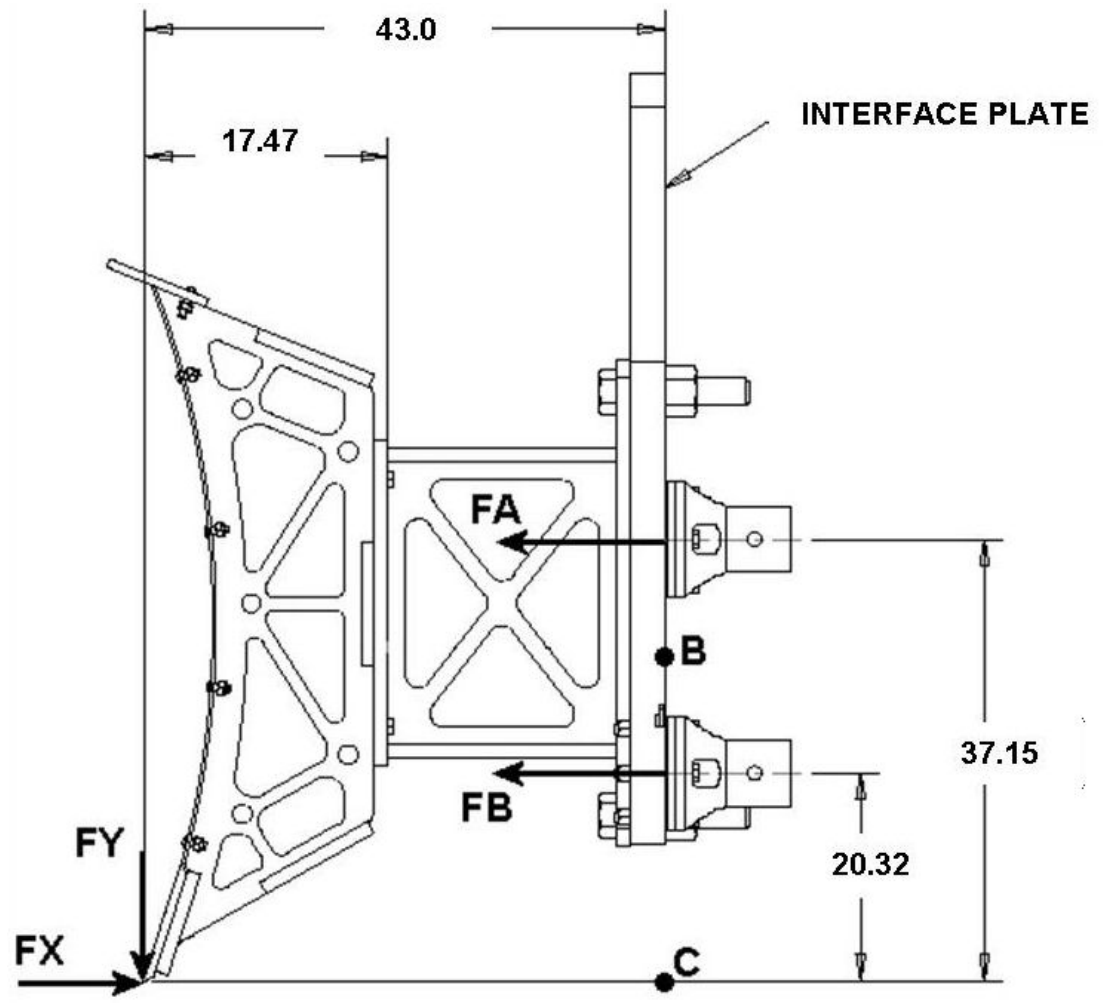

Figure 7.-Side view of blade showing top and bottom load cells for November test (dimensions in centimeters). 


\section{Data Post Processing}

The data from the field tests was tabulated in an Microsoft Excel spreadsheet and any data points where the vehicle stopped or went backwards or the blade lifted up were removed. This was necessary because the theoretical equations are not valid if the vehicle is traveling backwards or for a depth of cut above the soil which are negative values in the equations.

The data consisted of forces from the two top and three bottom load cells along with velocity and cut depth. The forces from the three bottom load cells were combined to get one bottom force (FB) and the two top load cell forces were combined to get one top force (FA) as shown in Figure 6 for the May test and Figure 7 for the November test. The load cell data was then reduced to get a horizontal and a vertical force at the blade tip by summing moments at two locations both in the same vertical plane of the interface plate where the load cell forces are applied. The first location (point B) was halfway between the load cells and the second location (point $\mathrm{C}$ ) was at the intersection of the interface plate plane and the soil surface.

Moments were summed at point $\mathrm{C}$ to get blade force FY (Newtons) and at point $\mathrm{B}$ to get blade force FX. The moment equations used to calculate the forces from the free body diagram are shown below in Equations (1) through (4) (dimensions are in centimeters). The weight of the blade was not included in the calculations since it was zeroed out before load cell data was taken. The blade force calculated here acts at a single point on the blade which is a combination of the forces along the length of the blade. This single blade force will allow the experimental forces to be compared to the theoretical forces predicted by the Balovnev model.

\section{May Test Moment Equations}

$$
\begin{gathered}
\Sigma \mathrm{MC}=31.79 \mathrm{FA}+14.96 \mathrm{FB}+37.49 \mathrm{FY}=0 \\
\Sigma \mathrm{MB}=8.42 \mathrm{FA}-8.42 \mathrm{FB}+37.49 \mathrm{FY}+23.38 \mathrm{FX}=0 \\
\text { November Test Moment Equations } \\
\Sigma \mathrm{MC}=37.15 \mathrm{FA}+20.32 \mathrm{FB}+43.0 \mathrm{FY}=0 \\
\Sigma \mathrm{MB}=8.42 \mathrm{FA}-8.42 \mathrm{FB}+43.0 \mathrm{FY}+28.73 \mathrm{FX}=0
\end{gathered}
$$

\section{Results}

The Excavation System force model predicts blade forces using the Balovnev equations (Ref. 4). Two separate equations were used. One derived for a bucket and the other for a blade. The horizontal force equation for the Balovnev bucket method is shown in Equation (5) and for the Balovnev blade method in Equation (7). The vertical force is calculated from Equation (6) for both methods using the horizontal force vector and the blade angles.

The experimentally measured horizontal blade force and the force predicted by the Balovnev bucket equations compare reasonably well given the assumptions and simplifications made in the data analysis. The Balovnev blade equations, as originally translated into the force model, did not compare as well as the Balovnev bucket equations. The calculated blade force diverged from the measured blade force as time increased. This is due to the soil pile increasing in front of the blade as the vehicle travels. The height of this pile is the soil prism height and is a variable in the blade equations that has a dominating effect on the calculated force which increased at a much greater rate than the actual measured forces for both test series.

Since this anomaly in the theoretical calculation from the Balovnev blade equations occurred for both test series, the soil prism height was studied in more detail. Balovnev uses the total height of the soil 
prism, which is shaped as a right triangle, in calculations. For curiosity, the soil prism height value input to the equations was reduced by three which would be the distance measured from the base of the soil pile to the centroid of the triangle. This would approximate the location of the vertically distributed blade horizontal force reduced to a single point force applied to the soil pile. A force applied to the top of a triangle would tip the triangle over rather than provide the necessary force for horizontal translation.

For the Balovnev bucket equations, there is an equivalent term in the equations called surcharge mass which is the mass per unit area of soil in front of the blade. This value was estimated for the bucket equations from the measured surcharge mass on the blade so both the blade and bucket equations include this effect. However, the surcharge mass does not have as great of an effect on the calculated force in the bucket equations as the soil prism height has in the blade equations.

Once this change was made to the soil prism height variable, the force predicted by the modified Balovnev blade equations followed the trend of the experimental data well. Without this modification, the Balovnev blade equations could not be used for comparison to the experimental data due to the significant divergence that was seen on both the May and November tests.

The soil properties, which were measured at the site prior to testing, and blade dimensions used in the equations are shown in Table 1. The measured and calculated forces from the Balovnev bucket equations, along with the blade depth, are plotted versus time for the May tests in Figures 8 and 11 and for the November test in Figures 14, 17, 20, and 23. The measured and calculated forces from the modified Balovnev blade equations, along with the blade depth, are plotted versus time for the May tests in Figures 9 and 12 and for the November test in Figures 15, 18, 21, and 24.

TABLE 1.-INPUT DATA TO BLADE FORCE EQUATIONS

\begin{tabular}{|c|c|c|c|c|}
\hline Description & Variable & \multicolumn{2}{|c|}{ Value } & Units \\
\hline \multicolumn{5}{|l|}{ Blade dimensions } \\
\hline Blade width & $w$ & \multicolumn{2}{|c|}{4.1148} & meter \\
\hline Blade side plate length & $l_{s}$ & \multicolumn{2}{|c|}{0} & meter \\
\hline Blade height from tip & $l$ & \multicolumn{2}{|c|}{0.51} & meter \\
\hline Blunt edge thickness & $e_{b}$ & \multicolumn{2}{|c|}{0.01524} & meter \\
\hline Blunt edge angle & $\alpha_{b}$ & \multicolumn{2}{|c|}{40} & degrees \\
\hline Side plate thickness & $s$ & \multicolumn{2}{|c|}{0} & meter \\
\hline Rake angle & $\beta$ & \multicolumn{2}{|c|}{72.1} & degrees \\
\hline Blade radius & $r$ & \multicolumn{2}{|c|}{0.66} & meter \\
\hline \multicolumn{2}{|l|}{ Soil parameters } & GRC-1 & GRC-3 & \\
\hline Soil density & $\gamma$ & 1600 & 1676 & kilogram $/$ meter $^{3}$ \\
\hline Cohesion & $c$ & 0 & 1500 & Newton/meter ${ }^{2}$ \\
\hline Internal friction angle & $\phi$ & 33 & 44 & degrees \\
\hline External friction angle & $\delta$ & 25 & 28 & degrees \\
\hline Surcharge mass & $q$ & \multicolumn{2}{|c|}{ variable vs. time } & kilogram $/$ meter $^{2}$ \\
\hline Soil prism height & $h$ & \multicolumn{2}{|c|}{ variable vs. time } & meter \\
\hline \multicolumn{5}{|l|}{ Test variables } \\
\hline Vertical cut depth & $d$ & \multicolumn{2}{|c|}{ variable vs. time } & meter \\
\hline Vehicle velocity & $v$ & \multicolumn{2}{|c|}{ variable vs. time } & meter $/ \mathrm{sec}$ \\
\hline \multicolumn{5}{|l|}{ Constants } \\
\hline Gravitational constant & $g$ & \multicolumn{2}{|c|}{9.81} & meter $/ \mathrm{sec}^{2}$ \\
\hline
\end{tabular}




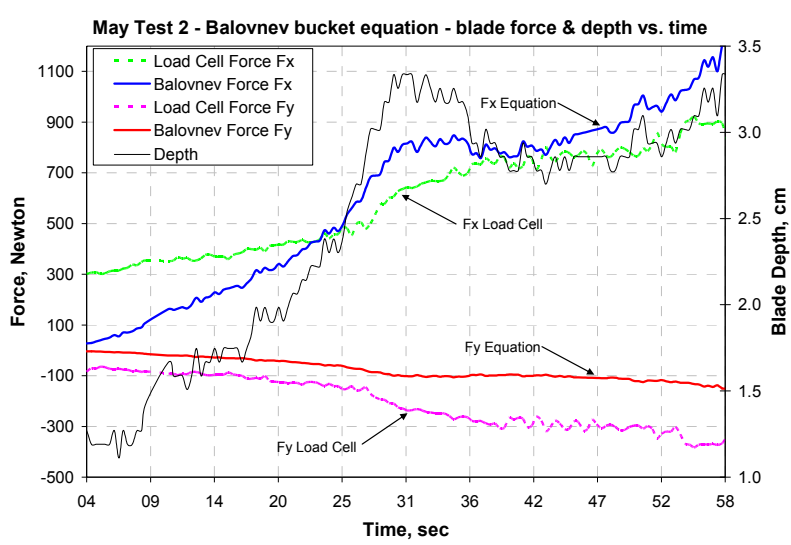

Figure 8.-Blade forces from May test 2 compared to Balovnev bucket equations.

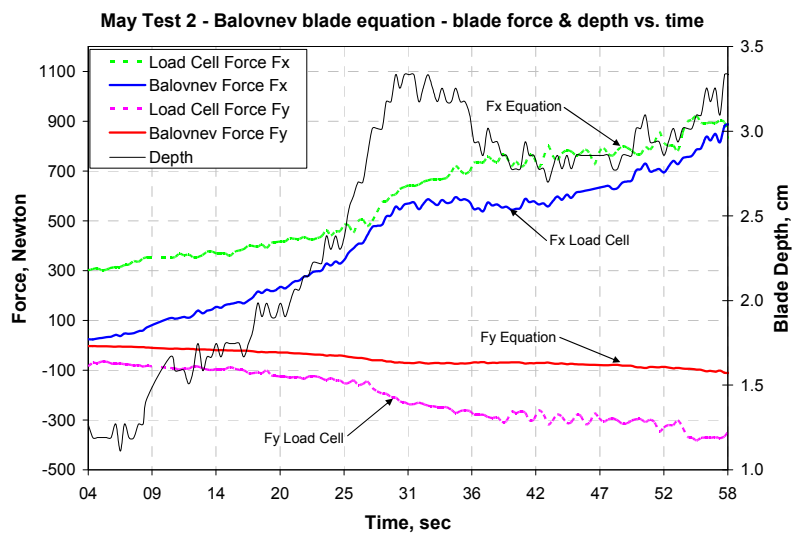

Figure 9.-Blade forces from May test 2 compared to Balovnev blade equations.

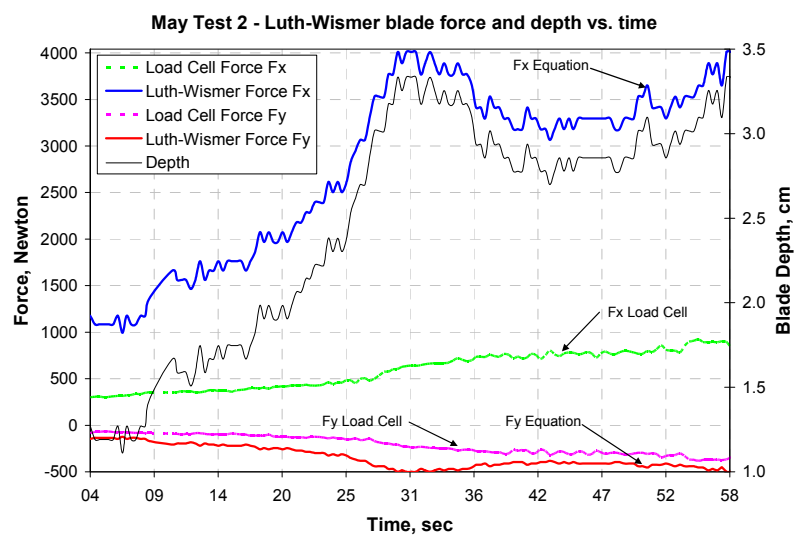

Figure 10.-Blade forces from May tests 2 compared to Luth-Wismer equations.

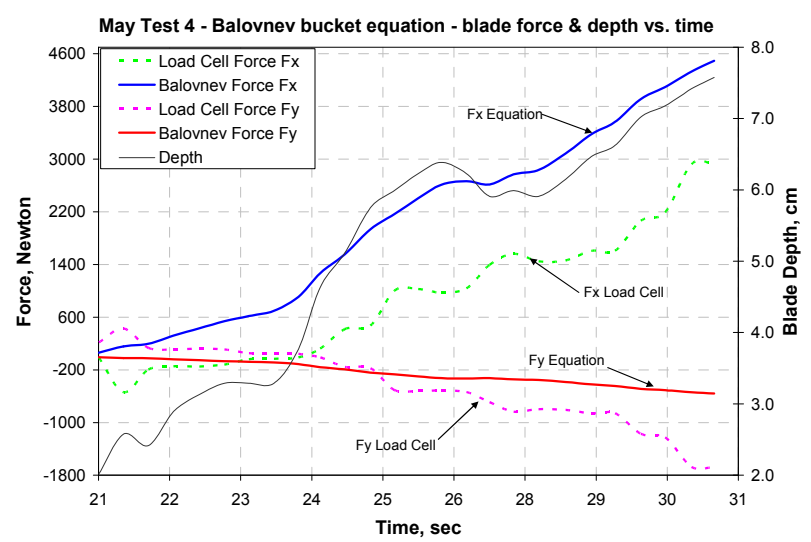

Figure 11.-Blade forces from May test 4 compared to Balovnev bucket equations.

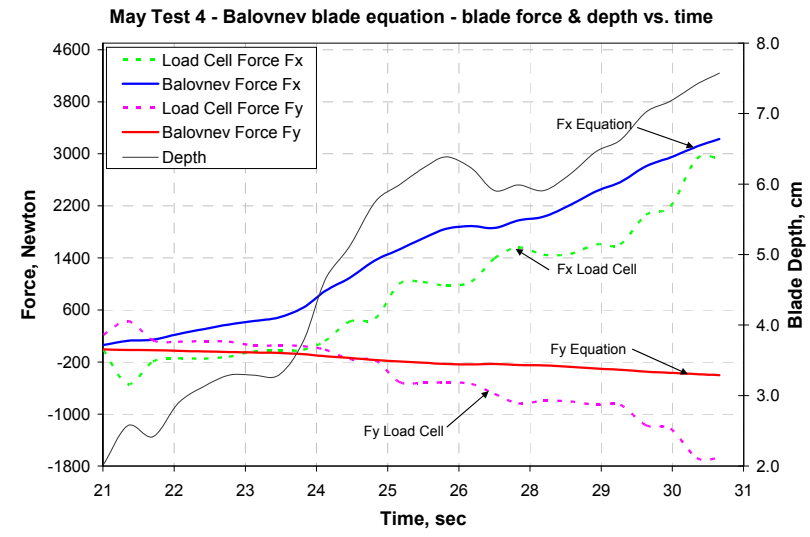

Figure 12.-Blade forces from May test 4 compared to Balovnev blade equations.

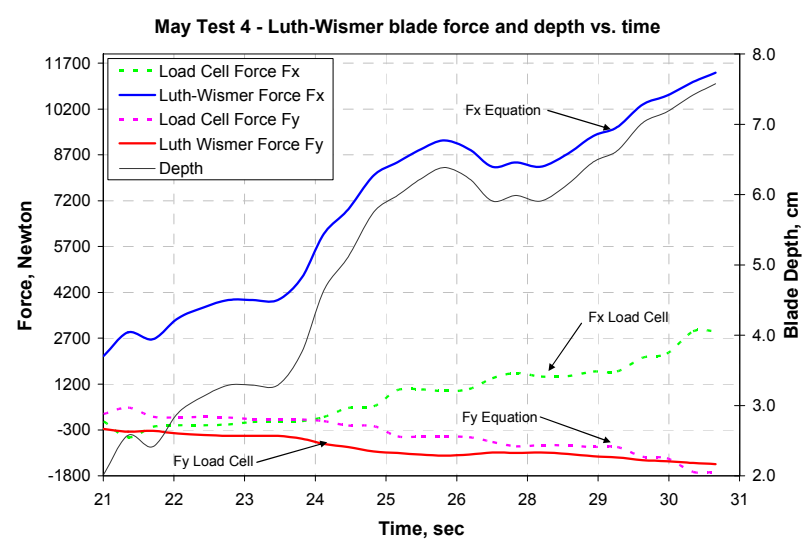

Figure 13.-Blade forces from May tests 4 compared to Luth-Wismer equations. 


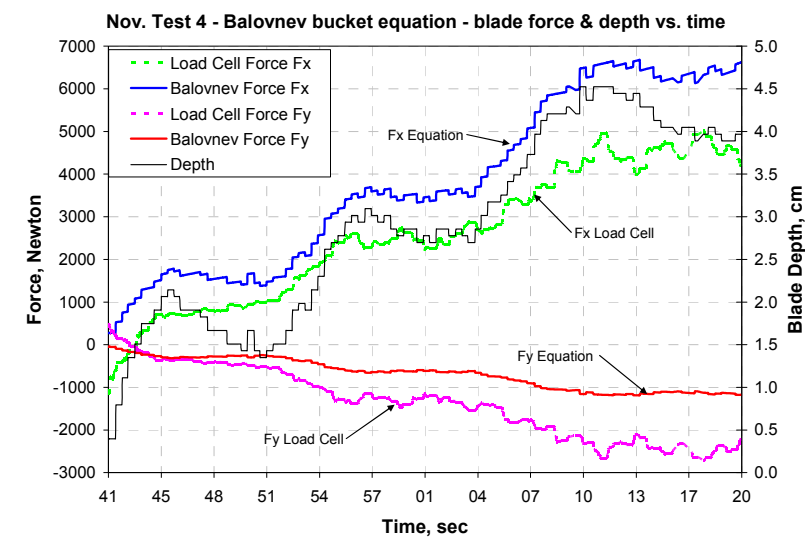

Figure 14.-Blade forces from November test 4 compared to Balovnev bucket equations.

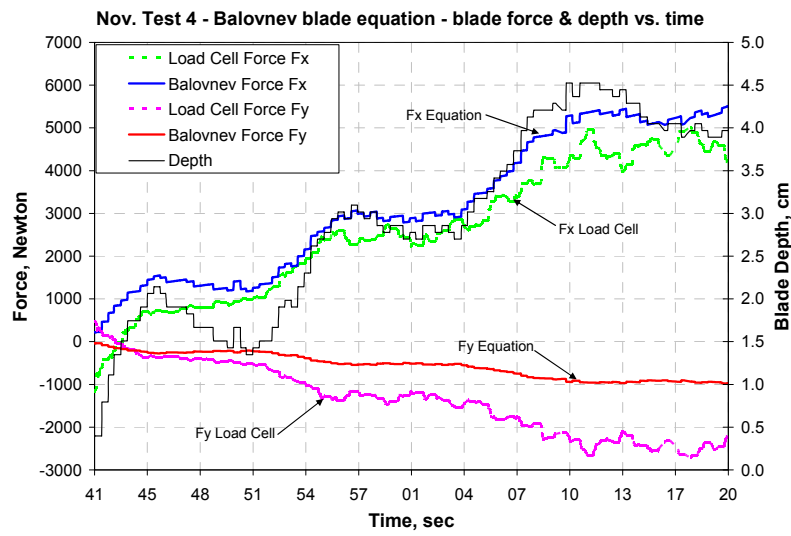

Figure 15.-Blade forces from November test 4 compared to Balovnev blade equations.

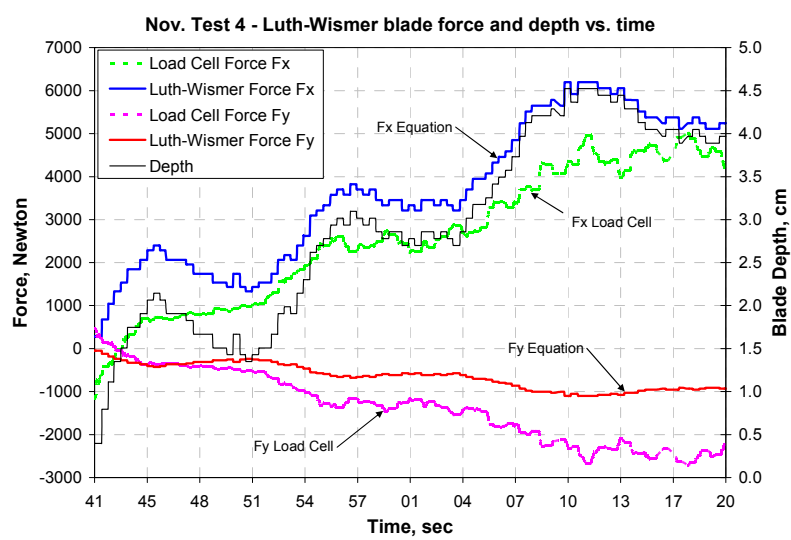

Figure 16.-Blade forces from November test 4 compared to Luth-Wismer equations.

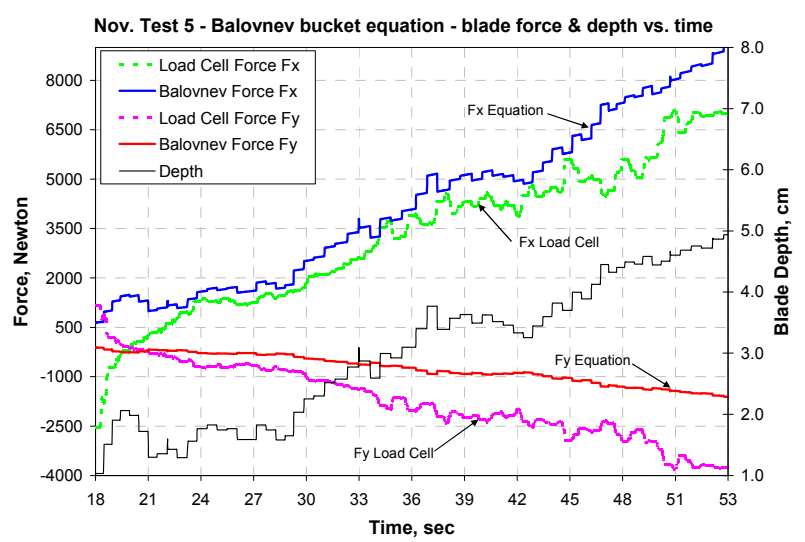

Figure 17.-Blade forces from November test 5 compared to Balovnev bucket equations.

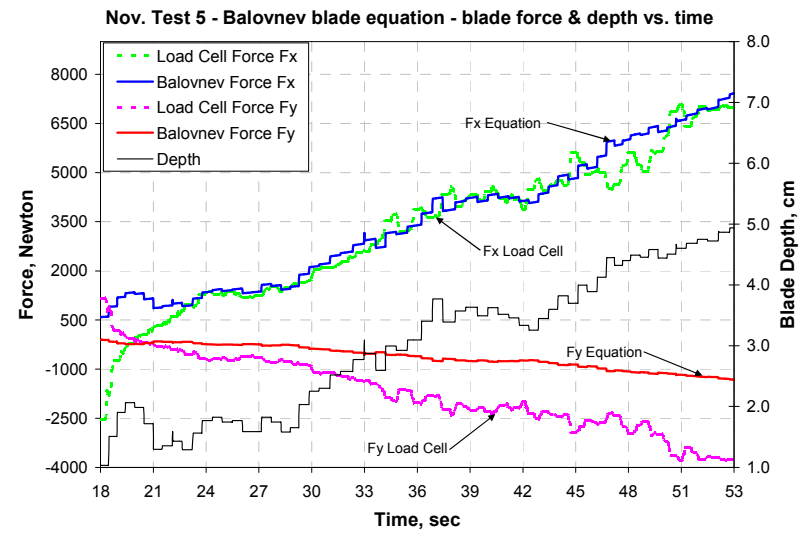

Figure 18.-Blade forces from November test 5 compared to Balovnev blade equations.

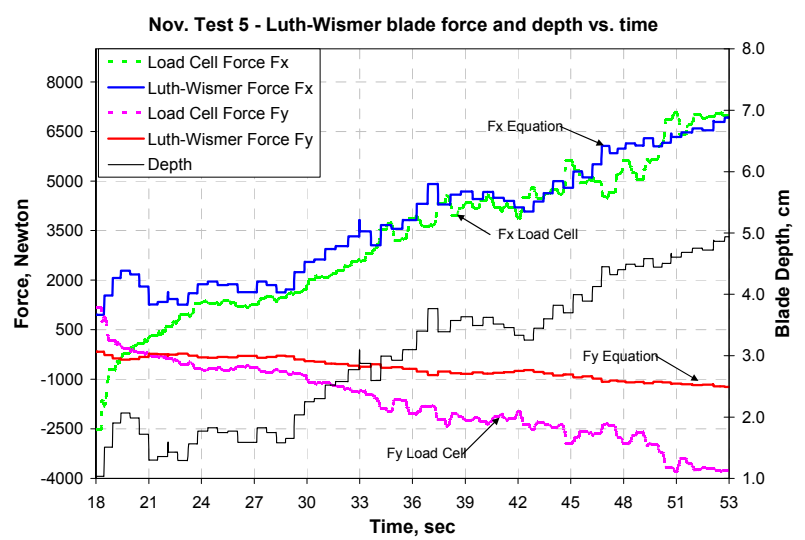

Figure 19.-Blade forces from November test 5 compared to Luth-Wismer equations. 


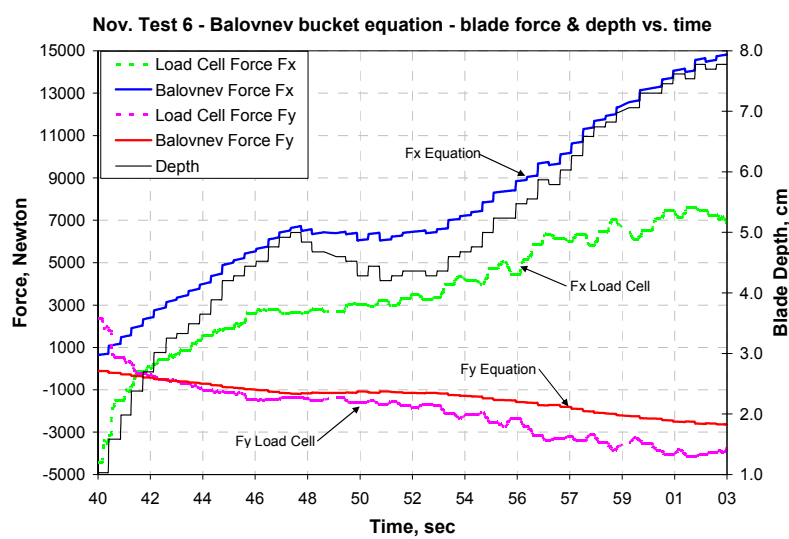

Figure 20.-Blade forces from November test 6 compared to Balovnev bucket equations.

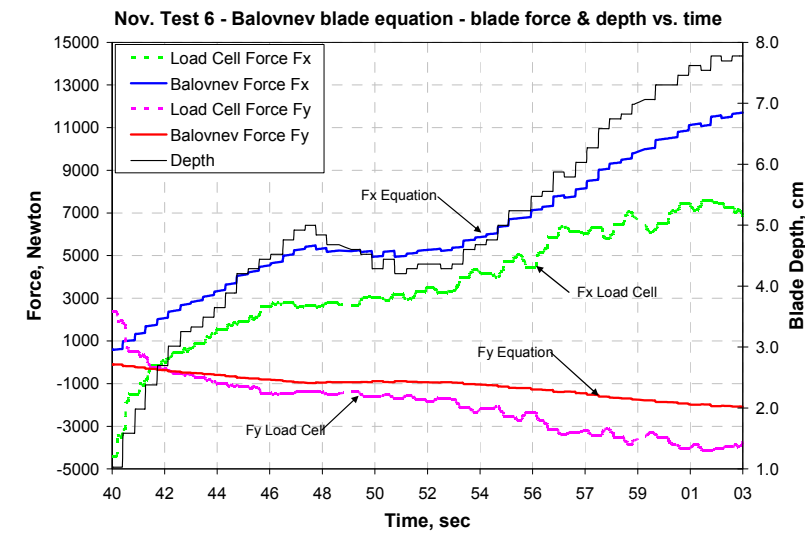

Figure 21._Blade forces from November test 6 compared to Balovnev blade equations.

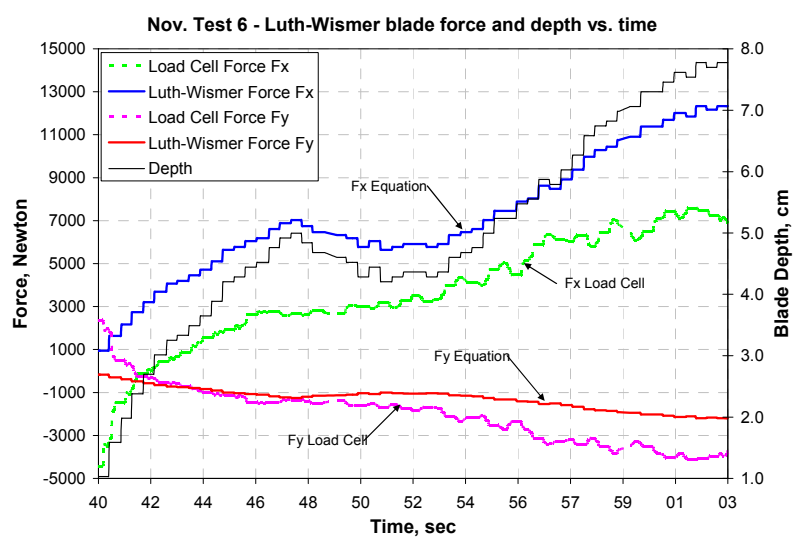

Figure 22.-Blade forces from November test 6 compared to Luth-Wismer equations.

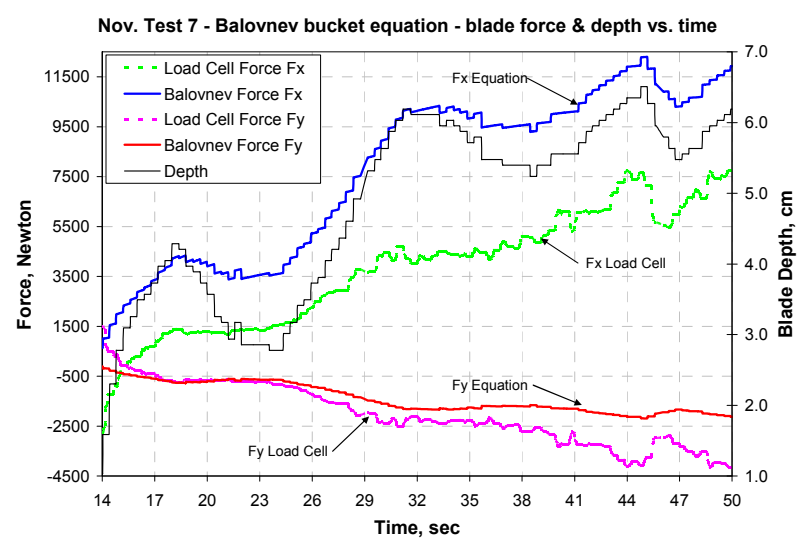

Figure 23.-Blade forces from November test 7 compared to Balovnev bucket equations.

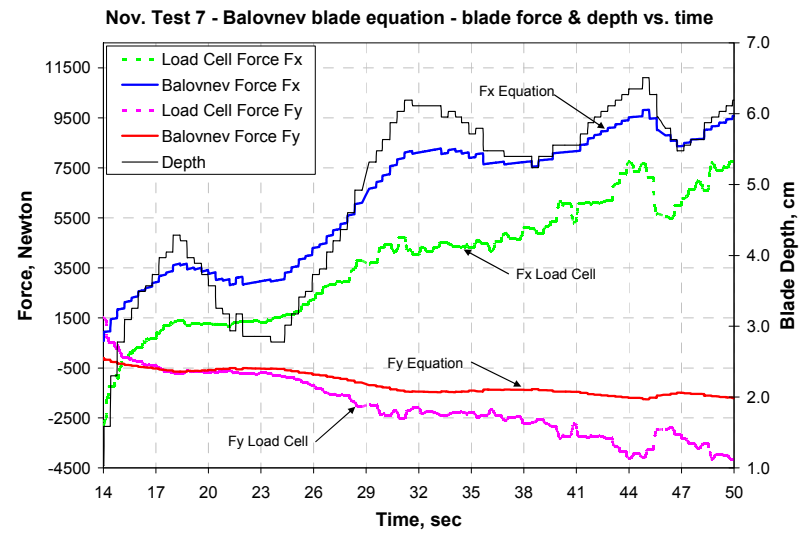

Figure 24.-Blade forces from November test 7 compared to Balovnev blade equations.

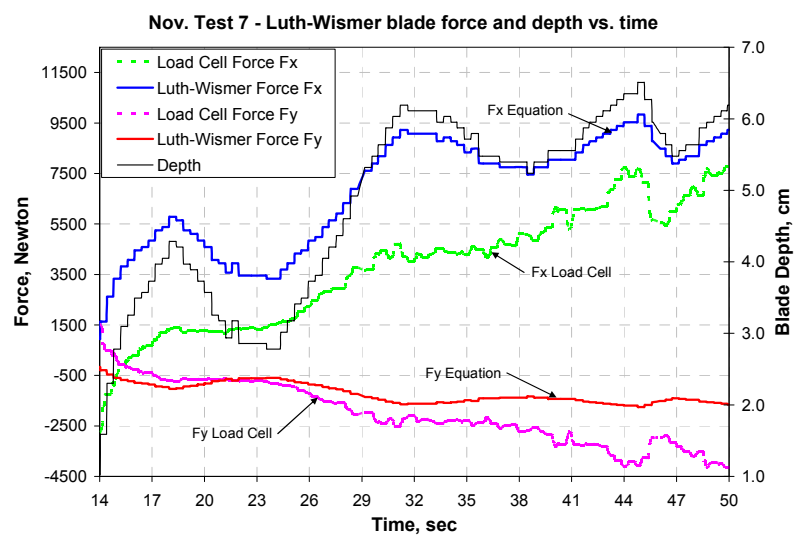

Figure 25.-Blade forces from November test 7 compared to Luth-Wismer equations. 
For the May series, test 2 lasted $55 \mathrm{sec}$ and 136 data points were recorded while test 4 included 26 data points over a period of $10 \mathrm{sec}$. For the November series, test 4 lasted $38 \mathrm{sec}$ and 1709 data points were recorded, test 5 included 1626 data points over $35 \mathrm{sec}$, test 6 included 1008 data points over $23 \mathrm{sec}$ and test 7 included 1623 data points over $36 \mathrm{sec}$. The horizontal blade force FX is the dominant force since the rake angle of the blade is $72^{\circ}$. As the rake angle approaches $90^{\circ}$, when the blade is completely vertical, the vertical force decreases towards zero.

The calibration of the load cells and the analytical method used to reduce the data could be other possibilities as to why the force from the Balovnev blade equations diverges but, with the same effect resulting for both test series, these theories are doubtful. For the May tests, the load cells were calibrated prior to mounting on the vehicle and a calibration factor was determined and applied to the measured forces from the test. However, there was no calibration performed on the load cells after they were mounted. For the November tests, the load cells were calibrated after mounting to the vehicle by attaching a cable to the blade that had an additional load cell attached to measure force. The vehicle was moved and the force applied to the cable load cell and the blade load cells was recorded and a calibration factor was determined and applied to the forces recorded during the tests.

There are five load cells located between the blade mounting structure and the vehicle. The Balovnev equations calculate the force at the tip of the blade in contact with the soil. The forces on the two horizontal rows of load cells are combined to get one equivalent load cell force for each row. This force is then translated to the tip of the blade through a free body diagram. The free body diagram is simple but there could be other factors that were not considered in the force translation. The blade force was assumed to be uniform along the length of the blade where in reality the force is probably variable since the cut depth into the sand was not constant along the blade length throughout the duration of the tests. The soil prism height was assumed to be constant along the length of the blade but the height varied also because of the nonuniform cut depth.

A third set of equations were used to predict the forces on the blade to provide an additional comparison to the measured forces. These equations, designated as the Luth-Wismer equations (Ref. 5), were developed specifically for a bulldozer blade type operation. The horizontal force equation for the Luth-Wismer method is shown in Equation (8). A comparison over the entire data range can be seen in Figures 10 and 13 for the May tests and Figures 16, 19, 22, and 25 for the November tests. As before, the vertical force, FY is small because of the high rake angle. The horizontal force, FX calculated by LuthWismer is roughly 10 times the force from the experimental data for the May test but tends to follow the experimental data for the November test. The blade vertical depth of cut into the soil has a noticeable effect on the results as seen from the plots. The force follows the trend of the vertical cut depth magnitude as time progresses. The force calculated from Luth-Wismer is a function of vehicle velocity whereas velocity is not a variable in Balovnev. The reasoning as to why the Luth-Wismer method predicted forces with such a great difference between the two test series is not known. The dependence of the equations on blade velocity and cut depth probably contributed to this difference. The load cell calibration and data collection methods were improved upon for the November test and the fact that the data was more accurate for the latter test could have contributed to this improvement. 


\section{Balovnev Bucket Force Equations}

Horizontal Blade Force $=$ $w d \mathrm{~A}_{1}(1+\cot \beta \tan \delta)\left[d g \gamma / 2+c \cot \phi+g q+\mathrm{BURIED}^{*}(d-1 \sin \beta) g \gamma(1-\sin \phi) /(1+\sin \phi)\right]+$ $w e_{b} \mathrm{~A}_{2}\left(1+\tan \delta \cot \alpha_{b}\right)\left(e_{b} g \gamma / 2+c \cot \phi+g q+d g \gamma(1-\sin \phi) /(1+\sin \phi)\right)+$ $d \mathrm{~A}_{3}\left(2 s+4 l_{s} \tan \delta\right)\left[d g \gamma / 2+c \cot \phi+g q+\mathrm{BURIED}^{*}\left(d-l_{s} \sin \beta\right) g \gamma(1-\sin \phi) /(1+\sin \phi)\right]$

where BURIED $=1$ if entire bucket is below the soil otherwise BURIED $=0$

$\mathrm{A}_{1}=\mathrm{A}(\beta)$
$\mathrm{A}_{2}=\mathrm{A}\left(\alpha_{b}\right)$
$\mathrm{A}_{3}=\mathrm{A}(\pi / 2)$

Replace ' $\mathbf{x}$ ' in the following equations with $\beta$ for $A_{1}, \alpha_{b}$ for $A_{2}$ or $\pi / 2$ for $A_{3}$

if $\mathbf{x}\left[0.5\left[\sin ^{-1}(\sin \delta / \sin \phi)-\delta\right]\right.$

$\mathrm{A}(\mathbf{x})=(1-\sin \phi \cos 2 \mathbf{x}) /(1-\sin \phi)$

if $\mathbf{x}>0.5\left[\sin ^{-1}(\sin \delta / \sin \phi)-\delta\right]$

$\mathrm{A}(\mathbf{x})=\left[\cos \delta\left(\cos \delta+\left(\sin ^{2} \phi-\sin ^{2} \delta\right)^{1 / 2}\right) /(1-\sin \phi)\right] \exp \left[\left(2 \mathbf{x}-\pi+\delta+\sin ^{-1}(\sin \delta / \sin \phi)\right) \tan \phi\right]$

Vertical Blade Force $=$ Horizontal Blade Force $* \cos (\beta+\delta) / \sin (\beta+\delta)$

\section{Balovnev Blade Force Equations}

If $\left(\beta<=\left(0.5 \sin ^{-1}(\sin \delta / \sin \phi)-\delta / 2\right)\right)$

$\mathrm{A} 1=(1-\sin \phi \cos (2 \beta)) /(1-\sin \phi)$

If $\left(\beta>\left(0.5 \sin ^{-1}(\sin \delta / \sin \phi)-\delta / 2\right)\right)$

$\mathrm{A} 1=\left(\cos \delta\left(\cos \delta+\left(\sin ^{2} \phi-\sin ^{2} \delta\right)^{0.5}\right)\right) /(1-\sin \phi) \operatorname{Exp}\left(\left(2 \beta-\pi+\delta+\sin ^{-1}(\sin \delta / \sin \phi)\right) \tan \phi\right)$

$\mathrm{A} 2=0.8 g \gamma w(\tan \delta+\tan \phi) \cos ^{2} \phi$

$\mathrm{A} 3=\sin ^{-1}(1 /(2 r / h))$

$\mathrm{A} 4=\mathrm{A} 2 r h /(2 \tan \delta)$

$\mathrm{A} 5=\mathrm{A} 2 \cos (\mathrm{A} 3) r^{2} /\left(1+\tan ^{2} \delta\right)$

$\mathrm{A} 6=\mathrm{A} 2 \sin (\mathrm{A} 3) r^{2} \tan \delta /\left(1+\tan ^{2} \delta\right)$

$\mathrm{A} 7=\operatorname{Exp}(2 \mathrm{~A} 3 \tan \delta)$

$\mathrm{A} 8=(\mathrm{A} 4+\mathrm{A} 5)(\mathrm{A} 7-1)-\mathrm{A} 6(\mathrm{~A} 7+1)$

$\mathrm{B} 1=\mathrm{A} 1 w g \gamma d^{2} \sin (\beta+\delta) / \sin \beta / \cos \delta / 2$

$\mathrm{B} 2=\mathrm{A} 1 d w c \sin (\beta+\delta) / \sin \beta / \cos \delta / \tan (\phi)$

$\mathrm{B} 3=\mathrm{A} 1 \mathrm{~A} 8 \sin (\beta+\delta) / \cos \delta /((\tan \beta+\operatorname{Tan}(\pi / 4-\phi / 2)) /(\tan \beta \operatorname{Tan}(\pi / 4-\phi / 2)))$

$\mathrm{B} 4=\mathrm{A} 10.8 g \gamma d w h \sin (\beta+\delta) / \sin \beta / \cos \delta$

$\mathrm{B} 5=0.8 g \gamma w h^{2} \cos ^{2} \phi / 2$

Horizontal Blade Force $=\mathrm{B} 1+\mathrm{B} 2+\mathrm{B} 3+\mathrm{B} 4+\mathrm{B} 5$

\section{Luth-Wismer Blade Force Equations}

Horizontal Blade Force $=\gamma g w d^{1 / 2} l^{1.5} \beta^{1.73}(d /(l \sin \beta))^{0.77}\left(1.05(d / w)^{1.1}+1.26 v^{2} / g / l+3.91\right)$ 


\section{Conclusion}

The blade forces predicted by the Balovnev bucket equations compare well to the forces derived from the test data and the forces predicted by the Balovnev blade equations compared well once the soil prism height was reduced by a factor of three. The Luth-Wismer equations were also used to calculate the blade force to provide a third theoretical calculation for comparison. The predicted forces for the May data were much greater than the actual force and the forces predicted from the November data matched the measured data much better. But there was an inconsistency between the predicted forces using LuthWismer that was not evident using the Balovnev equations. Different methods were used to calibrate the load cells for both test series and the blade force predicted by the Balovnev equations was consistent for both the May and November tests. There still may be improvements possible to the load cell calibration method and the force reduction to relate the measured data from the load cells to the force at the blade tip such as expanding the calibration and free body diagram to three-dimensions.

\section{References}

1. Balovnev, V.I., New Methods for Calculating Resistance to Cutting Soil, Amerind Publishing (Translation), P. Data, translator and Rosvuzizdat, New Delhi, Available from National Technical Information Service, Springfield, VA 22161, 1983 and 1963.

2. Gallo, C.A., Agui, J.H., Galloway, G.M. and Mueller, R.P., Excavating Regolith on the Moon Using the ISRU Force/Mass System Model, presented at the Planetary and Terrestrial Mining Sciences Symposium, Sudbury, Ontario, Canada, June 10-13, 2007.

3. Gallo, C.A., ISRU Excavation Vehicle Sizing and Trade Study Results, presented at the Planetary and Terrestrial Mining Sciences Symposium, Sudbury, Ontario, Canada, June 4-7, 2006.

4. Wilkinson, R.A and DeGennaro, A., Digging and Pushing Lunar Regolith: Classical Soil Mechanics and the Forces Needed for Excavation and Traction, Journal of Terramechanics, 44(2), 2007.

5. Luth, H.J. and Wismer, R.D., Performance of Plane Soil Cutting Blades in Sand, Transactions of the ASAE, vol. 14, pp. 255-262, 1971. 


\begin{tabular}{|c|c|c|c|c|c|}
\hline \multicolumn{5}{|c|}{ REPORT DOCUMENTATION PAGE } & $\begin{array}{l}\text { Form Approved } \\
\text { OMB No. 0704-0188 }\end{array}$ \\
\hline \multicolumn{6}{|c|}{$\begin{array}{l}\text { The public reporting burden for this collection of information is estimated to average } 1 \text { hour per response, including the time for reviewing instructions, searching existing data sources, gathering and maintaining the } \\
\text { data needed, and completing and reviewing the collection of information. Send comments regarding this burden estimate or any other aspect of this collection of information, including suggestions for reducing this } \\
\text { burden, to Department of Defense, Washington Headquarters Services, Directorate for Information Operations and Reports (07004-0188), } 1215 \text { Jefferson Davis Highway, Suite } 1204 \text {, Arlington, VA } 22202-4302 \text {. } \\
\text { Respondents should be aware that notwithstanding any other provision of law, no person shall be subject to any penalty for failing to comply with a collection of information if it does not display a currently valid OMB } \\
\text { control number. } \\
\text { PLEASE DO NOT RETURN YOUR FORM TO THE ABOVE ADDRESS. }\end{array}$} \\
\hline \multicolumn{2}{|c|}{$\begin{array}{l}\text { 1. REPORT DATE (DD-MM-YYYY) } \\
01-03-2010\end{array}$} & \multicolumn{3}{|c|}{$\begin{array}{l}\text { 2. REPORT TYPE } \\
\text { Technical Memorandum }\end{array}$} & 3. DATES COVERED (From - To) \\
\hline \multirow{2}{*}{\multicolumn{5}{|c|}{$\begin{array}{l}\text { 4. TITLE AND SUBTITLE } \\
\text { Comparison of ISRU Excavation System Model Blade Force Methodology and Experimenta } \\
\text { Results }\end{array}$}} & 5a. CONTRACT NUMBER \\
\hline & & & & & 5b. GRANT NUMBER \\
\hline & & & & & 5c. PROGRAM ELEMENT NUMBER \\
\hline \multirow{3}{*}{\multicolumn{5}{|c|}{$\begin{array}{l}\text { 6. AUTHOR(S) } \\
\text { Gallo, Christopher, A.; Wilkinson, R., Allen; Mueller, Robert, P.; Schuler, Jason, M.; Nick, } \\
\text { Andrew, J. }\end{array}$}} & 5d. PROJECT NUMBER \\
\hline & & & & & 5e. TASK NUMBER \\
\hline & & & & & $\begin{array}{l}\text { 5f. WORK UNIT NUMBER } \\
\text { WBS 387498.04.01.04.03 }\end{array}$ \\
\hline \multicolumn{5}{|c|}{$\begin{array}{l}\text { 7. PERFORMING ORGANIZATION NAME(S) AND ADDRESS(ES) } \\
\text { National Aeronautics and Space Administration } \\
\text { John H. Glenn Research Center at Lewis Field } \\
\text { Cleveland, Ohio 44135-3191 }\end{array}$} & $\begin{array}{l}\text { 8. PERFORMING ORGANIZATION } \\
\text { REPORT NUMBER } \\
\text { E-16880 }\end{array}$ \\
\hline \multirow{2}{*}{\multicolumn{5}{|c|}{$\begin{array}{l}\text { 9. SPONSORING/MONITORING AGENCY NAME(S) AND ADDRESS(ES) } \\
\text { National Aeronautics and Space Administration } \\
\text { Washington, DC 20546-0001 }\end{array}$}} & $\begin{array}{l}\text { 10. SPONSORING/MONITOR'S } \\
\text { ACRONYM(S) } \\
\text { NASA }\end{array}$ \\
\hline & & & & & $\begin{array}{l}\text { 11. SPONSORING/MONITORING } \\
\text { REPORT NUMBER } \\
\text { NASA/TM-2010-215591 }\end{array}$ \\
\hline \multicolumn{6}{|c|}{$\begin{array}{l}\text { 12. DISTRIBUTION/AVAILABILITY STATEMENT } \\
\text { Unclassified-Unlimited } \\
\text { Subject Category: } 29 \\
\text { Available electronically at http://gltrs.grc.nasa.gov } \\
\text { This publication is available from the NASA Center for AeroSpace Information, 443-757-5802 }\end{array}$} \\
\hline \multicolumn{6}{|c|}{ 13. SUPPLEMENTARY NOTES } \\
\hline \multicolumn{6}{|c|}{$\begin{array}{l}\text { 14. ABSTRACT } \\
\text { An Excavation System Model has been written to simulate the collection and transportation of regolith on the Moon. The calculations in this } \\
\text { model include an estimation of the forces on the digging tool as a result of excavation into the regolith. Verification testing has been } \\
\text { performed and the forces recorded from this testing were compared to the calculated theoretical data. A prototype lunar vehicle built at the } \\
\text { NASA Johnson Space Center (JSC) was tested with a bulldozer type blade developed at the NASA Kennedy Space Center (KSC) attached } \\
\text { to the front. This is the initial correlation of actual field test data to the blade forces calculated by the Excavation System Model and the test } \\
\text { data followed similar trends with the predicted values. This testing occurred in soils developed at the NASA Glenn Research Center (GRC) } \\
\text { which are a mixture of different types of sands and whose soil properties have been well characterized. Three separate analytical models are } \\
\text { compared to the test data. }\end{array}$} \\
\hline \multicolumn{6}{|c|}{$\begin{array}{l}\text { 15. SUBJECT TERMS } \\
\text { Insitu resource utilization; Space exploration; Oxygen production; Lunar mining }\end{array}$} \\
\hline \multicolumn{3}{|c|}{ 16. SECURITY CLASSIFICATION OF: } & $\begin{array}{l}\text { 17. LIMITATION OF } \\
\text { ABSTRACT }\end{array}$ & $\begin{array}{l}\text { 18. NUMBER } \\
\text { OF }\end{array}$ & $\begin{array}{l}\text { 19a. NAME OF RESPONSIBLE PERSON } \\
\text { STI Help Desk (email:help@sti.nasa.gov) }\end{array}$ \\
\hline $\begin{array}{l}\text { a. REPORT } \\
\text { U }\end{array}$ & $\begin{array}{l}\text { b. ABSTRACT } \\
\text { U }\end{array}$ & $\begin{array}{l}\text { c. THIS } \\
\text { PAGE } \\
\text { U }\end{array}$ & UU & $\begin{array}{l}\text { PAGES } \\
19\end{array}$ & $\begin{array}{l}\text { 19b. TELEPHONE NUMBER (include area code) } \\
443-757-5802\end{array}$ \\
\hline
\end{tabular}



